\title{
HISTORY OF CULTURE AND EDUCATION
}

DOI: 10.46340/ephd.2020.6.4.1

\author{
Yurii Roik \\ ORCID ID: https://orcid.org/0000-0001-5968-8848 \\ Taras Shevchenko National University of Kyiv, Ukraine \\ THE PALACES OF VINNYTSIA REGION \\ IN THE SYSTEM OF RECORD AND PROTECTION \\ OF CULTURAL HERITAGE FROM 1917 \\ TO NOWADAYS
}

Юрій Роїк

Київський національний університет імені Тараса Шевченка, Україна

\section{ПАЛАЦИ ВІННИЦЬКОЇ ОБЛАСТІ В СИСТЕМІ ОБЛІКУ \\ ТА ОХОРОНИ КУЛЬТУРНОЇ СПАДЩИНИ З 1917 РОКУ ДО СУЧАСНОСТІ}

\begin{abstract}
This article considers the processes of formation and development of the monument protection activities after 1917 to the present times, and the place of the palaces of the Vinnytsia region in these processes. A significant part of the palace heritage of Ukraine was lost after the revolutionary events of 1917 . The government had to regulate legislation on protection of the monuments to stop the destructive tendencies. The system of cultural heritage protection was founded during the times of the Ukrainian People's Republic and was maintained later during the time of the Hetmanate and the Directorate. Under Soviet rule, the monument's protection activities intensified and subsided at various times. At the same time, the pre-Soviet cultural heritage was periodically destroyed. Ukrainian legislation has made significant progress in the process of protection of monuments, but even today there are a number of issues related to the protection and preservation of the palace heritage of the country.

Keywords: Palace, architectural monument, monument protection activity, record, Vinnytsia region.
\end{abstract}

Сьогодні на території Вінницької області зосереджена значна частина пам'яток палацовопаркової архітектури України, збудованої в кінці XVIII - на початку XX століття. Завершилась ця епоха революцією 1917 року та встановленням радянської влади на території України. Розкішні маєтки не відповідали більшовицькій ідеології і зазнавали руйнування або перепрофільовувались під заклади лікування, навчальні заклади, школи-інтернати, будинки культури тощо. Часто будівлі перебудовувались, значну частину об'єктів було втрачено назавжди, а зі збережених лише деякі перебувають в задовільному стані.

Дослідженням становлення та розвитку пам'яткоохоронної діяльності на території України в різні часи займались В. Акуленко, В. Горбик, Г. Денисенко, А. Скрипник, М. Жарких, В. Бадяк, П. Тронько. Актуальні питання збереження і охорони національної культурної спадщини висвітлено в працях С. Кота, Н. Кудерської. В працях дослідників увага зосереджена на загальних аспектах становлення та розвитку системи державного управління та охорони культурної спадщини в цілому. Також існує ряд праць, присвячених окремим історико-культурним об'єктам. Серед всіх пам'яток найменше уваги приділялося історії охорони поміщицьких палаців. Тому метою даної статті $є$ дослідження особливостей законодавчої бази та пам'яткоохоронної діяльності з 1917 року до сьогодні та визначення місця палаців Вінницької області в ній. Важливим є вивчення питання збереження та використання об’єктів палацової спадщини в XX столітті та в наші дні.

Після революційних подій 1917 року становище поміщиків кардинально похитнулось. В умовах відсутності державного управління часто страждала приватна власність дворян та заможних людей. Софія Грохольська, очевидиця подій 1917 року, писала в своїх спогадах: “Коли в Росії вибухнула Революція, то першим прикладом здичавіння і розлючення російських солдатів було вбивство 
беззахисного старця - князя Романа Сангушка в Славуті. Це сталося 1 листопада 1917 року, 3 того часу щораз доходили до нас звістки, що той або інший громадянин дивом врятувався з сім'єю, коли пограбували його дім"1. Значна частина палаців Вінницької області була пошкоджена або знищена після 1917 року. Часто грабували та підпалювали палаци самі ж місцеві селяни.

За часів УНР розпочалось формування системи охорони культурної спадщини на державному рівні. Першим державним органом за Української Центральної Ради став Центральний комітет охорони пам'яток старовини і мистецтва. Він займався обліком та реєстром пам'яток, проведенням різноманітних досліджень та запобігав вивезенню культурних цінностей за межі України. Головою комітету, відомим археологом та музеєзнавцем М. Біляшівським було розроблено проєкт закону "Про охорону пам'яток старовини та мистецтва"2. В законі було положення про заборону знесення, пребудови або реставрації пам'яток старовини будь-якої власності без дозволу комітету. Визначалась державна власність на всі види пам'яток'

Завдяки зусиллям комітету вдалось зберегти від руйнування низку садиб, палацових комплексів та церков. Створений при Генеральному секретаріаті Відділ охорони пам'яток старовини і мистецтва зі сторінок всеукраїнської "Робітничої газети” закликав громадян утриматися від нищення та грабунку панських садиб та необхідності передачі всіх цінностей в музеї, де вони зможуть служити всьому народу ${ }^{4}$.

За Гетьманату та доби Директорії продовжилась робота над законом "Про охорону пам'яток старовини і мистецтва". Напрацьований в цей час досвід у формуванні системи охорони культурної спадщини в майбутньому був втілений у Законах України "Про охорону культурної спадщини" (2000 р.) i “Про вивезення, ввезення та повернення культурних цінностей” (1999 року)

Зі встановленням радянської влади вціліле нерухоме майно переходило в державну власність, для палаців Вінниччини розпочинався новий, далеко не найкращий етап. Юридично перехід права поміщицької власності до трудящих закріплювався в Декреті про землю від 5 лютого 1920 рокуб. А вже в законі від 5 квітня 2021 року встановлювалися механізми конфіскації майна7.

У 20-ті роки XX століття відбуваються зрушення в радянській політиці щодо пам'яткоохоронної діяльності на території України. Зокрема на Поділлі 3 березня 1921 року було утворено Подільський губревком губернського комітету охорони пам'яток старовини, природи і мистецтва. Незабаром Комітети були створені в різних містах регіону, одним з основних векторів діяльності яких була реєстрація та взяття на облік пам'яток історії та культури, зокрема і архітектури (Кам'янецька фортеця, Вінницькі “Мури”, садиба Пирогова) ${ }^{8}$.

16 червня 1926 року ВУЦВК та РНК РСР України було прийнято “Положення про пам'ятники культури й природи". Це був один з перших законів, спрямованих на захист історико-культурних пам'яток України за часів СРСР.

Цікавим для дослідження є ставлення до поміщицьких палаців в цей час. 3 однієї сторони бачимо протягом декількох років, починаючи з 1917-го, масовий грабунок та знищення палаців. Зазвичай грабунком займались малоосвічені верстви населення. 3 іншої сторони, знаходились дослідники, які розуміли значення архітектурних споруд та навіть намагались, хоч і не прямо, обгрунтовувати необхідність їх захисту та збереження. Для прикладу, в праці Василя Дубровського “Охорона пам'яток культури в УСРР” 1927 року знаходимо роздуми щодо цього. Для ефективного використання та охорони автор пропонує поділ пам'яток на категорії:

- передісторичні чи археологічні;

- будівельні чи архітектурні (сюди ж входять і палаци);

\footnotetext{
${ }^{1}$ Грохольська, С. (2018). Болючі спогади 1917-1919. Вінниця: Генріх Грохольський, 25.

2 Горбик, В. О., Денисенко, Г. Г. (2012). “Звід пам'яток історії та культури Украйни” у дослідженні і охороні культурної спадщини: досвід, проблеми, перспективи. Київ: Поліграф. д-ця Ін-ту історії України НАН України, 11.

3 Денисенко, О. А. (2014). Історична ретроспектива становлення пам'яткоохоронного законодавства в Україні. Наукові записки Інституту законодавства Верховної Ради України, 3, 7.

${ }^{4}$ Біляшівський, М. (2000). Охорона пам'яток старовини. Робітнича газета <http://irbis-nbuv.gov.ua/cgibin/irbis_ir/ cgiirbis_64.exe?Z21ID=\&I21DBN=ELIB\&P21DBN=ELIB\&S21STN=1\&S21REF=10\&S21FMT=online_G\&C21COM= $\mathrm{S} \& S 21 \mathrm{CNR}=20 \& S 21 \mathrm{P} 01=0 \& S 21 \mathrm{P} 02=0 \& S 21 \mathrm{P} 03=\mathrm{FF}=\& S 21 \mathrm{STR}=00004559 / 189>(2020$, листопад, 10).

5 Денисенко, О. А. (2014). Історична ретроспектива становлення пам'яткоохоронного законодавства в Україні. Наукові записки Інституту законодавства Верховної Ради України, 3, 9.

${ }^{6}$ Рада Народних Комісарів, Народний комісаріат юстиції (1921). Збірник узаконень та розпоряджень

Всеукраӥнського револючійного комітету за 1919-1920 роки. Харків: Шоста радянська друкарня, 1, 14.

${ }^{7}$ Марочко, В. І. (2013). Соціальний статус та політичні права колишніх поміщиків у совіцікій Україні 1920-х років. Вісник Львівської комериійної академії. Серія: Гуманітарні науки, 11, 249.

${ }^{8}$ Баженов, Л. В. (1993). Поділля в прачях дослідників і краєзнавців XIX-XX ст.: Історіографія. Бібліографія.

Матеріали. Кам'янець-Подільський, 46.
} 
- меморіальні;

- історико-культурні заповідники.

Продовжуючи думку можливого поділу Дубровський зазначає, що церкви, для прикладу, можна було б віднести до підгрупи культового будівництва, а поміщицькі садиби - до підгрупи побутових пам'яток ${ }^{1}$. Автор наголошує, що саме діяльність людей $є$ причиною знищення більшості пам'яток історії та культури. Як протидія деструктивним процесам пропонується популяризація охорони пам'яток культури серед працюючих масㄹ․

Протягом 20-х років XX століття декларативно держава наче і піклувалась про пам'яткоохоронну діяльність, проте фактична робота часто базувалась на ентузіазмі дослідників на місцях. Комітети охорони пам'яток і старовини, утворенні на Поділлі на початку 20-х років, гостро відчували недофінансування. Відсутність належної уваги та підтримки зі сторони влади спонукали дослідниківкраєзнавців покидати таку діяльність ${ }^{3}$. Результати пам'яткоохоронної діяльності відрізнялись і в різних регіонах. Всього на території УСРР в 1926-1928 рр. було зареєстровано 375 пам'яток архітектури. 3 них Київською крайовою інспектурою - 137. В Тульчинській окрузі - 6 пам'яток, в у Вінницькій $-1^{4}$.

Незважаючи на бурхливу діяльність щодо становлення пам'яткоохоронної системи, яка розпочалась з початку існування радянської влади, виявлявся нахил до нищення національної історико-культурної спадщини 5 . Починаючи 330 -х років XX століття посилюється ідеологізація культури, що також вплинуло і на пам'яткоохоронну сферу. Найбільше в цей період постраждали об'єкти культової архітектури. Діяльність в сфері охорони пам'яток затухає, а багатьох дослідників 20 -х років було репресовано.

30 грудня 1948 рік було прийняте “Положення про охорону пам'яток культури на території Української РСР”. Пам'ятки поділялись на: архітектури, мистецтва, археології, історичні, республіканського і всесоюзного значення. Продовжилась робота над державним реєстром пам'яток, до якого було внесено 47 тис. одиниць. Переважна більшість пам'яток були пов'язані з подіями війни: військові поховання, могили радянських воїнів. На території Вінницької області з 3445 об'єктів, взятих на облік, 3415 були могилами радянських воїнів. Так намітилась тенденція на тотальне скорочення пам'яток дорадянської історії України ${ }^{6}$. Невирішеним залишалось питання стосовно відомчого підпорядкування пам'яток, що позначилось на загальному стані будівель. Одним зі способів використання нерухомих об'єктів культурної спадщини стало перепрофілювання архітектурних пам'яток (замків, палаців, монастирів, храмів) під інтернати, лікарні, клуби, школи.

Важливою у вивченні використання палацово-паркових комплексів є Постанова Ради Міністрів УРСР від 24 серпня 1963 р. № 970 “Про впорядкування справи обліку та охорони пам’ятників архітектури на території Української РСР" ". В цій постанові відмічаються серйозні недоліки в справі обліку, охорони і збереження пам'яток культури. Звертається увага на те, що проведені у 1962 році обстеження виявили, що чимало старовинних споруд втратили свою історичну та художню цінність внаслідок руйнування та перебудов. Державний реєстр пам'яток було значно скорочено. Зазначалось, що до переліку пам'яток, які перебувають під охороною держави, внесено велику кількість споруд культового призначення. Саме цей тип пам'яток було скорочено найбільше. Держбуду УРСР було доручено вирішувати питання пристосування та реконструкції пам'яток для практичного використання.

Положення поділяє пам'ятки за групами, згідно способу їх використання: перша група - ті, які не можна використовувати в практичних цілях; друга група - ті, які можна використовувати під наукові та музейно-показові установи; третя група - ті, які можна використовувати для культурних або господарських цілей і передавати в орендне використання ${ }^{8}$.

\footnotetext{
${ }^{1}$ Дубровський, В. (1927). Охорона пам'яток культури в УСРР. Харків: 1-а Держ. літо-друк, 9.

2 Дубровський, В. (1930). Історично-культурні заповідники та пам'ятки України. Харків:

Держ. вид-во України, 27.

${ }^{3}$ Баженов, (1993). Поділля в праиях дослідників і краєзнавців XIX-XX ст.: Iсторіографія. Бібліографія.

Матеріали. Кам'янець-Подільський, 46.

4 Дубровський, В. (1930). Історично-культурні заповідники та пам'ятки України. Харків:

Держ. вид-во України, 57-58.

${ }^{5}$ Горбик, В. О., Денисенко, Г. Г. (2012). “Звід пам'яток історії та культури України” у дослідженні і охороні культурної спадщини: досвід, проблели, перспективи. Київ: Поліграф. д-ця Ін-ту історії України НАН України, 15.

${ }^{6}$ там само, 22.

${ }^{7}$ Постанова про впорядкування справи обліку та охорони пам'ятників архітектури на території

Української РСР, 1963 (Рада Міністрів Української РСР). Офіиійний сайт Верховної Ради України

<https://zakon.rada.gov.ua/laws/show/970-63-\%D0\%BF\#Техt> (2020, листопад, 10).

${ }^{8}$ Там само.
} 
Палаци Вінницької області, що увійшли до списку пам'яток архітектури Української РСР від 24 серпня 1963 р.

\begin{tabular}{|l|l|l|}
\hline \multicolumn{1}{|c|}{ Назва } & \multicolumn{1}{c|}{ Розташування } & \multicolumn{1}{c|}{ Будівництво } \\
\hline Палац Грохольських & смт. Вороновиця & $1770 \mathrm{p.}$ \\
\hline Палац Потоцьких & м. Тульчин & $1782 \mathrm{p}$. \\
\hline Палац Потоцьких-Щербатових & м. Немирів & $1885 \mathrm{p}$. \\
\hline Палац Ланге & с. Нападівка & поч. ХІХ ст. \\
\hline
\end{tabular}

Джерело: Постанова Ради Міністрів УРСР від 24 серпня 1963 р. № 970 "Про впорядкування справи обліку та охорони пам'ятників архітектури на території Української РСР", .

Характерно, що всі ці палаци було віднесено до третьої групи, тобто передано для використання в культурних або господарських цілях.

В 1966 році було створено громадську пам'яткоохоронну організацію УТОПІК. До неї входило багато краєзнавців, письменників, митців. Організація займалась як теоретичною розробкою методології охорони пам'яток так і практичною діяльністю ${ }^{2}$.

У вересні 1979 року видано постанову № 442 “Про доповнення списку пам'яток містобудування і архітектури Української РСР, що перебувають під охороною держави”"3. За цією постановою ще 14 палаців Вінницької області було взято на облік. Як і за постановою 1963 року всі палаци було передано для використання в культурних або господарських цілях.

Таблиця 2

\section{Палаци Вінницької області, що доповнили список пам'яток архітектури Української РСР від 6 вересня 1979 р.}

\begin{tabular}{|l|c|c|}
\hline \multicolumn{1}{|c|}{ Назва } & Розташування & Будівництво \\
\hline Палац Чацького & с. Серебринці & кін XVIII ст. \\
\hline Палац Грохольських & м. Вінниця & кін. XVIII ст. \\
\hline Палац Тишкевичів & с. Андрушівка & кін. XVIII-поч. XIX ст. \\
\hline Палац Комара & м. Муровані Курилівці & 1805 p. \\
\hline Палац Чорномських & с. Чорномин & 20-ті рр. XIX ст. \\
\hline Палац Вітославського-Львова & с. Чернятин & кін. XVIII ст. \\
\hline Палац Четвертинських & с. Антопіль & кін. XVIII ст. \\
\hline Палац Собанських & с. Спичинці & пол. XIX ст. \\
\hline Палац Потоцьких & смт. Дашів & 1887 р. \\
\hline Палац Ценіної & с. Котюжани & поч. XX ст. \\
\hline Палац Собанських & с. Верхівка & кін. XIX ст. \\
\hline Палац Четвертинських-Балашових & с. Комаргород & п.п XIX ст. \\
\hline Палац Мерінга & с. Стара Прилука & поч. XX ст. \\
\hline Палац Левашових-Ксідо & м. Хмільник & 1916 р. \\
\hline
\end{tabular}

Дюсерело: Постанова Ради Міністрів УРСР від 6 вересня № 442 "Про доповнення списку пам'яток містобудування і архітектури Украӥнської РСР, щзо перебувають під охороною держави".

\footnotetext{
${ }^{1}$ Постанова про впорядкування справи обліку та охорони пам'ятників архітектури на території Украйнської РСР, 1963 (Рада Міністрів Української РСР). Офіиійний сайт Верховної Ради Украӥни <https://zakon.rada.gov.ua/laws/show/970-63-\%D0\%BF\#Техt> (2020, листопад, 10).

${ }^{2}$ Горбик, В. О., Денисенко, Г. Г. (2012). “Звід пам'яток історії та культури Украӥни” у дослідженні і охороні культурної спадщини: досвід, проблеми, перспективи. Київ: Поліграф. д-ця Ін-ту історії України НАН України, 27.

${ }^{3}$ Постанова про доповнення списку пам'яток містобудування і архітектури Украӥнської РСР, щуо перебувають під охороною держави, 1979 (Рада Міністрів Української РСР). Офіиіийний сайт Верховної Ради Украӥни <https://zakon.rada.gov.ua/laws/show/442-79-\%D0\%BF\#Техt> (2020, листопад, 10).

${ }^{4}$ Там само.
} 
Сьогодні пам'ятки які увійшли до переліків 1963 та 1979 років мають статус національного значення, включені до Державного реєстру нерухомих пам'яток України та охороняються державою. Іншим об'єктам рішеннями виконкому обласних рад міг надаватись статус пам'ятки місцевого значення.

Таблиця 3

\section{Палаци Вінницької області, які мають статус пам'ятки архітектури місцевого значення}

\begin{tabular}{|c|c|c|c|}
\hline Назва & Розташування & Будівництво & Номер і дата рішення \\
\hline $\begin{array}{l}\text { Замок-палац } \\
\text { Холоневського }\end{array}$ & с. Іванів & $\begin{array}{c}\text { XVIII ст.- } \\
\text { перебудований }\end{array}$ & $\begin{array}{l}\text { Рішення виконкому облради нар. деп. } \\
\text { від 17.02.83 № } 96\end{array}$ \\
\hline Палац Ярошинських & смт. Тиврів & $\begin{array}{l}\text { кін. XVIII ст.- } \\
\text { XIX ст. }\end{array}$ & $\begin{array}{l}\text { Рішення виконкому облради нар. деп. } \\
\text { від 14.02.91 № } 43\end{array}$ \\
\hline Палац Бахметьєвих & с. Носківці & поч. ХIX ст. & Розпорядження ОДА № 78 від 19.02.96 p \\
\hline Палац Собанських & с. Михайлівці & поч. XIX ст & $\begin{array}{l}\text { Рішення виконкому облради нар. деп. } \\
\text { від 14.02.91 № } 43\end{array}$ \\
\hline Палац Орловських & с. Северинівка & $1802-1804 \mathrm{pp}$. & Розпорядження ОДА № 78 від 19.02.96 р. \\
\hline Палац Рудзських & с. Біличин & 40-i pp. XIX ст. & $\begin{array}{l}\text { Рішення виконкому облради нар. деп. } \\
\text { від 14.02.91 № } 43\end{array}$ \\
\hline Палац Бжозовських & с. Соколівка & поч. ХІХ ст. & $\begin{array}{l}\text { Рішення виконкому облради нар. деп. } \\
\text { від 14.02.91 № } 43\end{array}$ \\
\hline Палац Вітгенштейнів & с. Брониця & кін. ХІХ ст. & $\begin{array}{l}\text { Рішення виконкому облради нар. деп. } \\
\text { від 14.02.91 № } 43\end{array}$ \\
\hline Палац Кошарського & с. Гонорівка & кін. XIX ст. (1850) & Розпорядження ОДА № 78 від 19.02 .96 р. \\
\hline Садиба фон Мекк & смт. Браїлів & $1868 \mathrm{p}$. & Розпорядження ОДА № 78 від 19.02 .96 р. \\
\hline $\begin{array}{l}\text { Маєток адмірала } \\
\text { Чихачова }\end{array}$ & с. Митки & $1860-1870 \mathrm{pp}$. & $\begin{array}{l}\text { Рішення виконкому облради нар. деп. } \\
\text { від 14.02.91 № } 43\end{array}$ \\
\hline Палац Шостаковського & с. Бугаївка & 1893 p. & $\begin{array}{l}\text { Рішення виконкому облради нар. деп. } \\
\text { від 14.02.91 № } 43\end{array}$ \\
\hline Палац Шереметьєва & с. Тиманівка & кін. ХIX ст. & $\begin{array}{l}\text { Рішення виконкому облради нар. деп. } \\
\text { від 14.02.91 № } 43\end{array}$ \\
\hline Палац Заботіних & с. Мала Ростівка & поч. ХХ ст. & $\begin{array}{l}\text { Рішення виконкому облради нар. деп. } \\
\text { від 14.02.91 № } 43\end{array}$ \\
\hline Палац Ярошинських & с. Бабин & $1963 \mathrm{p}$. & $\begin{array}{l}\text { Рішення виконкому облради нар. деп. } \\
\text { від 14.02.91 № } 43\end{array}$ \\
\hline Садиба Абамеликових & с. Гущинці & поч. ХІХ ст. & $\begin{array}{l}\text { Рішення виконкому облради нар. деп. } \\
\text { від 21.01.1986 № } 33\end{array}$ \\
\hline Палац Когана & с. Вищеольчедаїв & кін. ХIX ст. & $\begin{array}{l}\text { Рішення виконкому облради нар. деп. } \\
\text { від 14.02.1991 р. № } 43\end{array}$ \\
\hline Палац Собанських & с. Ободівка & $1908 \mathrm{p}$. & $\begin{array}{l}\text { Рішення виконкому облради нар. деп. } \\
\text { від 14.02.91 № } 43\end{array}$ \\
\hline $\begin{array}{l}\text { Замок-палац } \\
\text { Швейковських }\end{array}$ & м. Шпиків & XVIII ст. & $\begin{array}{l}\text { Рішення виконкому облради нар. деп. } \\
\text { від 14.02.91 № } 43\end{array}$ \\
\hline Палац Стаховського & м. Вінниця & 1907-1912 pp. & $\begin{array}{l}\text { Рішення виконкому облради нар. деп. } \\
\text { від 17.02.83 № } 96\end{array}$ \\
\hline $\begin{array}{l}\text { Палац Михальських- } \\
\text { Бібікових }\end{array}$ & с. Верхівка & поч. ХІХ ст. & $\begin{array}{l}\text { Розпорядження представник Президента } \\
\text { України ОДА від 14.07.94 р. № } 209\end{array}$ \\
\hline
\end{tabular}

Джерело: Інтерактивна база пам'яток містобудування та архітектури'.

\footnotetext{
${ }^{1}$ Вінницька обласна державна адміністрація (2020). Інтерактивна база пам'яток містобудування та архітектури <http://www.vin.gov.ua/departament-budivnytstva-mistobuduvannia-ta-arkhitektury/heoportal/22269-interaktyvnabaza-pamiatok-mistobuduvannia-ta-arkhitektury> $(2020$, листопад, 10).
} 
В 1983-1986 pр. було видано довідник “Пам'ятники містобудування та архітектури УРСР”. Видання не було офіційним документом і в ньому згадувались лише об'єкти, які були внесені до категорії пам'яток архітектури. Це був найповніший список збережених архітектурних пам'яток України за часів СРСР. Про палаци Вінницької області інформація міститься в другому томі довідника ${ }^{1}$.

Проголошення незалежності України поклало початок нового етапу пам'яткоохоронної діяльності. В 2000 році було прийнято Закон України “Про охорону культурної спадщини". Закон дає визначення загальних термінів, класифікацію об’єктів культурної спадщини за типами і видами, говорить про державне управління у сфері охорони культурної спадщини та необхідність створення Державного реєстру нерухомих пам'яток України. В законі визначено порядок внесення чи вилучення пам'яток з Державного реєстру. Внесені в реєстр пам'ятки можуть бути національного або місцевого значення ${ }^{2}$.

В 2009 році був прийнятий закон України “Про перелік пам'яток культурної спадщини, що не підлягають приватизації”. Згідно з документом “Пам'ятка може бути приватизована лише за умови укладення майбутнім власником з відповідним органом охорони культурної спадщини попереднього договору на пам'ятку (іï частину) з викладенням його істотних умов, у тому числі щодо цільового використання пам'ятки, робіт, які майбутній власник зобов'язується провести на пам'ятці $з$ метою утримання іï в належному стані”’.

Закон затверджує перелік пам'яток що не підлягають приватизації та включає 240 пам'яток у Вінницькій області. В цей перелік включено більшість наявних сьогодні палаців Вінницької області - 33 об'єкта. За кордоном існує поширена практика продажу палаців та замків у приватну власність або передачу в концесію (довгострокову експлуатацію). Існує чимало прикладів успішного використання таких пам'яток: проведення екскурсій, переобладнання під готель, здача в оренду для проведення весіль чи інших заходів. При цьому законодавство повинно регулювати всі можливі зміни, які відбуваються з пам’яткою.

Україна $є$ членом низки міжнародних організацій, які займаються охороною пам'яток культури і мистецтва. Сьогодні питання охорони і збереження різних пам'яток археології, архітектури тощо регулюється нормативно-правовими актами різних галузей права. Закон "Про охорону культурної спадщини" (2000р.) постійно допрацьовується та розширюється. Управління в сфері охорони культурної спадщини здійснюється органами виконавчої влади. Згідно Закону України "Про охорону культурної спадщини” уповноваженим органом є Міністерство Культури. Розгалужене українське законодавство надає повноваження в межах їх компетенцій також іншим міністерствам. Це робить систему не цілісною, розбалансованою та малоефективною. Існують проблеми з веденням обліку пам'яток, оскільки до сьогодні досі відсутній єдиний реєстр нерухомих пам'яток України ${ }^{4}$.

Таким чином, пам'яткоохоронна діяльність на території України була розпочата ще за часів УНР. Незважаючи на важке політичне, соціальне та економічне становище керівництво держави усвідомлювало важливість збереження культурної спадщини для майбутніх поколінь. Ця діяльність продовжилась за часів Гетьманату та Директорії.

Радянська влада декларувала своїм обов'язком охорону і збереження культурних пам'яток, але це по меншій мірі стосувалось пам'яток чужих для неї культур. Методи збереження пам'яток були досить суперечливими, більшість колишніх палаців передавались під використання в господарських цілях. Це зберегло їх від руйнування, але завдало неповоротних втрат зовнішньому вигляду та автентичності. Пам'яткоохоронна діяльність, розпочата в 20-х роках, характеризувалась відсутністю належної уваги до палаців.

\footnotetext{
1 Жариков, Н. Л. (ред.). (1983). Памятники градостроительства и архитектуры Украинской ССР: Ил. справ.-каталог.. Киев: Будівельник, 2, 336.

2 Закон України Про охорону культурної спадщини, 2000 (Верховна Рада України). Офіиійний сайт Верховної Ради України <https://zakon.rada.gov.ua/laws/show/1805-14\#Text> (2020, листопада, 10).

3 Закон України про перелік пам'яток культурної спадщини, щзо не підлягають приватизації, 2009 (Верховна Рада України). Офімійний сайт Верховної Ради Украӥни 〈https://zakon.rada.gov.ua/laws/show/574-17\#Text> (2020, листопада, 10).

${ }^{4}$ Кот, С. І. (2018). Про стан збереження культурної спадщини України. (Інформаційно-аналітичні матеріали до парламентських слухань “Стан, проблеми та перспективи охорони культурної спадщини в Україні” 18 квітня 2018 р.). Київ: Інститут історії України НАН України, 10.
} 
До сьогодні значна частина палаців Вінницької області продовжує використовуватись в господарських цілях. Згідно із законодавством вони були передані під заклади освіти, лікувальні заклади, сільські ради, а іноді навіть під житлові будинки (палац Ярошинських, с. Бабин Іллінецького району). Часто пам'ятки національного значення, будучи надбанням всього народу України, $\epsilon$ об’єктами з обмеженим доступом для відвідувачів.

3 проголошенням незалежності розпочався процес формування національного пам'яткоохоронного законодавства. Завдяки проведеним заходам з постановки на державний облік, зберігання і залучення пам'яток культури в господарську діяльність до наших днів вдалось зберегти частину об'єктів. Далеко не всі заходи були успішними, а законодавство і досі потребує серйозного доопрацювання. Необхідно продовжувати реформування національного пам'яткоохоронного законодавства. Це дасть можливість не просто зберегти культурну спадщину, а й повноцінно реалізувати ії потенціал у розвитку країни.

\section{References:}

1. Bazhenov, L. V. (1993). Podillia v pratsiakh doslidnykiv i kraieznavtsiv XIX-XX st.: Istoriohrafiia. Bibliohrafiia. Materialy [Podillia in the works of researchers and local historians of the XIX - XX centuries: Historiography. Bibliography. Materials]. Kamianets-Podilskyi. [in Ukrainian].

2. Biliashivskyi, M. (2020). Okhorona pamiatok starovyny [Protection of ancient monuments]. Robitnycha hazeta [Worker's newspaper]. <http://irbis-nbuv.gov.ua/cgi-bin/irbis_ir/cgiirbis_64.exe?Z21ID=\&I21DBN=ELIB\&P21DBN= ELIB $\& S 21 \mathrm{STN}=1 \& S 21 \mathrm{REF}=10 \& S 21 \mathrm{FMT}=$ online_G\&C21COM=S\&S21CNR=20\&S21P01 =0\&S21P02=0\&S21 $\mathrm{P} 03=\mathrm{FF}=\& S 21 \mathrm{STR}=00004559 / 189>(2020$, November, 10). [in Ukrainian].

3. Denysenko, O. A. (2014). Istorychna retrospektyva stanovlennia pam'iatkookhoronnoho zakonodavstva v Ukraini [Historical retrospective of the formation of monument protection legislation in Ukraine]. Naukovi zapysky Instytutu zakonodavstva Verkhovnoi Rady Ukrainy [Scientific notes of the Institute of Legislation of the Verkhovna Rada of Ukraine], 3, 5-9. [in Ukrainian].

4. Dubrovskyi, V. (1930). Istorychno-kulturni zapovidnyky ta pam'iatky Ukrainy [Historical and cultural reserves and monuments of Ukraine]. Kharkiv: Derzh. vyd-vo Ukrainy. [in Ukrainian].

5. Dubrovskyi, V. (1927). Okhorona pamiatok kultury v USRR [Protection of cultural monuments in the USSR]. Kharkiv: 1-a Derzh. lito-druk. [in Ukrainian].

6. Horbyk, V. O., Denysenko, H. H. (2012). "Zvid pam'iatok istorii ta kultury Ukrainy" u doslidzhenni i okhoroni kulturnoi spadshchyny: dosvid, problemy, perspektyvy ["Collection of Monuments of History and Culture of Ukraine" in the study and protection of cultural heritage: experience, problems, prospects]. Kyiv: Polihraf. d-tsia In-tu istorii Ukrainy NAN Ukrainy. [in Ukrainian].

7. Hrokholska, S. (2018). Boliuchi spohady 1917-1919 [Painful memories of 1917-1919] (A. Belinskyi transl.). Vinnytsia: Published by Henryk Hrocholski. [in Ukrainian].

8. Kot, S. I. (2018). Pro stan zberezhennia kulturnoi spadshchyny Ukrainy. (Informatsiino-analitychni materialy do parlamentskykh slukhan "Stan, problemy ta perspektyvy okhorony kulturnoi spadshchyny v Ukraini" 18 kvitnia $2018 \mathrm{r}$.) [On the state of preservation of the cultural heritage of Ukraine. (Information and analytical materials for the parliamentary hearings "Status, problems and prospects of cultural heritage protection in Ukraine" April 18, 2018)]. Kyiv: Instytut istorii Ukrainy NAN Ukrainy. [in Ukrainian].

9. Vinnytska oblasna derzhavna administratsiia [Vinnytsia Regional State Administration] (2020). Interaktyvna baza pamiatok mistobuduvannia ta arkhitektury [Interactive database of monuments of urban planning and architecture] <http://www.vin.gov.ua/departament-budivnytstva-mistobuduvannia-ta-arkhitektury/heoportal/22269-interaktyvnabaza-pamiatok-mistobuduvannia-ta-arkhitektury> [in Ukrainian]. (2020, November, 10).

10. Marochko, V. I. (2013). Sotsialnyi status ta politychni prava kolyshnikh pomishchykiv u sovitsikii Ukraini 1920-kh rokiv [Social status and political rights of former landowners in Soviet Ukraine in the 1920s]. Visnyk Lvivskoi komertsiinoi akademii. Seriia: Humanitarni nauky [Bulletin of the Lviv Commercial Academy. Series: Humanities], 11, 247-257. [in Ukrainian].

11. Postanova pro vporiadkuvannia spravy obliku ta okhorony pamiatnykiv arkhitektury na terytorii Ukrainskoi RSR, 1963 [Resolution on streamlining the record and protection of architectural monuments in the territory of the Ukrainian SSR, 1963]. (Rada Ministriv Ukrainskoi RSR) [Cabinet of Ministers of the Ukrainian RSR]. Ofitsiynyy sayt Verkhovnoyi Rady Ukrayiny [Official site of the Verkhovna Rada of Ukraine] <https://zakon.rada.gov.ua/laws/show/970-63-\%D0\%BF\#Text> (2020, November, 10). [in Ukrainian].

12. Postanova pro dopovnennia spysku pamiatok mistobuduvannia i arkhitektury Ukrainskoi RSR, shcho perebuvaiut pid okhoronoiu derzhavy vid 6 veresnia, 1979 [Resolution on supplementing the list of monuments of urban planning and architecture of the Ukrainian SSR under state protection, 1979]. (Rada Ministriv Ukrainskoi RSR) [Cabinet of Ministers of the Ukrainian RSR]. Ofitsiynyy sayt Verkhovnoyi Rady Ukrayiny [Official site of the Verkhovna Rada of Ukraine] <https://zakon.rada.gov.ua/laws/show/442-79-\%D0\%BF\#Text>. (2020, November, 10). [in Ukrainian]. 
13. Rada Narodnykh Komisariv, Narodnyi komisariat yustytsii (1921). Zbirnyk uzakonen ta rozporiadzhen Vseukrainskoho revoliutsiinoho komitetu za 1919-1920 roky [Collection of laws and prescriptions of All-Ukrainian revolution committee for 1919-1920]. Kharkiv: Shosta radianska drukarnia, 1. [in Ukrainian].

14. Zakon Ukrainy Pro okhoronu kulturnoi spadshchyny, 2000 [Law of Ukraine on Cultural Heritage Protection, 2000] (Verkhovna Rada Ukrainy) [Verkhovna Rada of Ukraine]. Ofitsiynyy sayt Verkhovnoyi Rady Ukrayiny [Official site of the Verkhovna Rada of Ukraine] <https://zakon.rada.gov.ua/laws/show/1805-14\#Text> (2020, November, 10). [in Ukrainian].

15. Zakon Ukrainy Pro perelik pamiatok kulturnoi spadshchyny, shcho ne pidliahaiut pryvatyzatsii, 2009 [Law of Ukraine on the list of cultural heritage monuments that are not subject to privatization]. (Verkhovna Rada Ukrainy) [Verkhovna Rada of Ukraine]. Ofitsiynyy sayt Verkhovnoyi Rady Ukrayiny [Official site of the Verkhovna Rada of Ukraine] <https://zakon.rada.gov.ua/laws/show/574-17\#Text> (2020, November, 10). [in Ukrainian].

16. Zharikov, N. L. (ed.). (1983). Pamjatniki gradostroitelstva i arhitektury Ukrainskoj SSR [Monuments of urban planning and architecture of the Ukrainian SSR: Ill. reference directory]. Kiev: Budivelnik, 2. [in Russian]. 